\title{
BENZODIAZEPINE RECEPTORS: LOCALIZATION IN RAT AMYGDALA ${ }^{1}$
}

\author{
D. L. NIEHOFF AND M. J. KUHAR ${ }^{2}$
}

Departments of Neuroscience, Pharmacology and Experimental Therapeutics, and Psychiatry and the Behavioral Sciences, The Johns Hopkins University School of Medicine, Baltimore, Maryland 21205

Received November 17, 1982; Revised April 25, 1983; Accepted April 28, 1983

\begin{abstract}
Behavioral, electroencephalographic, and evoked potential studies, as well as experiments utilizing the direct intracerebral injection of benzodiazepines (BZs), have implicated the amygdala, particularly its basolateral nuclear division, as an important locus of the therapeutic actions of these drugs. $\mathrm{BZ}$ receptor localization within the amygdala could further define which amygdaloid nuclei are important for BZ action and suggest neuroanatomical pathways especially sensitive to these drugs.

Using a quantitative light microscopic autoradiographic technique, this study has localized type 1 and type $2 \mathrm{BZ}$ receptors within the amygdaloid nuclear complex of the rat. BZ receptors were labeled with $\left[{ }^{3} \mathrm{H}\right]$ flunitrazepam, and type $1 \mathrm{BZ}$ receptor binding was preferentially displaced by CL218,872 in $8-\mu \mathrm{m}$ coronal sections of rat brain. Autoradiograms were generated by the apposition of emulsion-coated coverslips and quantified by standardized procedures.

Ten amygdaloid nuclei were examined at nine levels over the rostrocaudal extent of the amygdala. Total BZ receptor density was highest in the basolateral nuclear complex, and the majority of these receptors were of the type 2 subclass. Type 1 receptors were concentrated in the anterior aspects of the amygdala, particularly the anterior cortical nucleus.

These results are consistent with an important role for the basolateral amygdala in anxiogenesis and seizure induction. Furthermore, a larger circuit which includes the amygdala, ventromedial hypothalamus, mammillary body, anterior thalamus, and frontal cortex could be involved in the anxiolytic actions of the $\mathrm{BZ}$ drugs.
\end{abstract}

The benzodiazepines (BZs) are important anxiolytic and anticonvulsant drugs (Haefely et al., 1981). Localization of the sites of action of the BZs could provide important clues in elucidating neural pathways involved in the etiology of anxiety and seizure disorders. Electroencephalographic (Eidelberg et al., 1965; Haller, 1979) and evoked potential studies (Unmeto and Olds, 1975; Chou and Wang, 1977) seeking to identify such loci of $\mathrm{BZ}$ action pointed to the limbic system, particularly the amygdaloid nuclear complex. Involvement of the amygdala in the anxiolytic actions of the BZs might be anticipated in view of the extensive evidence implicating this structure in the expression of emotional, particularly

\footnotetext{
${ }^{1}$ We wish to thank Mrs. Theresa Kopajtic, Mrs. Naomi Taylor, and Mrs. Roberta Proctor for technical assistance and Ms. Darlene Weimer and Mrs. Mary Flutka, and Ms. Maureen Dever for clerical assistance. This work was supported by United States Public Health Service Grants MH00053 and DA00266, and grants from the McKnight Foundation and Lederie Laboratories.

${ }^{2}$ To whom correspondence should be addressed, at Department of Neuroscience, The Johns Hopkins University School of Medicine, 725 N. Wolfe Street, Baltimore, MD 21205.
}

fearful, behavior. In a variety of mammalian species, stimulation of the basolateral nuclear division of the amygdala evokes fearful or defensive behavior (Ursin and Kaada, 1960; Ursin, 1971), whereas lesions of this region result in a reduction in such behavior (Pellegrino, 1968; Swartzwelder, 1980). In humans, electrical stimulation of the amygdaloid complex produced a subjective sensation of fear or anxiety, as well as autonomic responses characteristic of fear, such as increases in heart rate and blood pressure, and pupillary dilation (Chapman et al., 1954). A role for the amygdala in the anticonvulsant actions of BZs is suggested by the vulnerability of this structure to the induction of "kindled" seizures and by the ability of intra-amygdaloid kainic acid to elicit a fatal myoclonic seizure pattern in rats similar to status epilepticus (Ben-Ari et al., 1979). Studies involving the direct application of BZs to the amygdala have elicited the anxiolytic and anticonvulsant effects of these drugs. For example, direct application of diazepam to the anterior amygdala of cats resulted in EEG alterations as well as attenuation of the carbachol-induced "rage" reaction, a measure of emotionality (Nagy and Desci, 
1973), while in rabbits, direct application of diazepam to the anterior amygdala strongly elevated the pentylenetetrazol-induced seizure threshold (Nagy and Desci, 1979). In studies utilizing the conflict paradigm in rats as a measure of anxiolytic potency, direct bilateral injection of diazepam into the amygdala resulted in increases in lever pressing during shock periods (Nagy et al., 1979). Several other recent studies have also reported that direct application of midazolam into the lateral and basolateral (Scheel-Kruger and Petersen, 1982) or central (Shipata et al., 1982) amygdaloid nuclei increased punished responding in a conflict paradigm.

Thus, it would be reasonable to hypothesize that the amygdala would contain significant levels of receptors for BZs, particularly in its more anterior aspects and in the lateral and basolateral nuclei. Autoradiographic evidence confirmed the existence of $\mathrm{BZ}$ receptors in the lateral nucleus at a medial level of the amygdala (Young and Kuhar, 1980). The discovery of the triazolopyridazine (TPZ) drugs, typified by CL218,872 (3-methyl-6-[3(trifluoromethyl)phenyl]-1,2,4-triazolopyridazine), allowed the division of $\mathrm{BZ}$ receptors into type 1 (high affinity for 'TPZs) and type 2 (low affinity for 'TP'Ls) subclasses (Lippa et al., 1979a, b; Klepner et al., 1979; Squires et al., 1979). Because CL218,872 is highly effective in increasing punished behavior and protects against pentylenetetrazol-induced seizures, but is nonsedating, it was originally proposed that type 1 receptors may be of greater importance in mediating the therapeutic effects of BZs (Lippa et al., 1979a, b; Squires et al., 1979). Hence, the amygdala might be expected to be a region enriched in type 1 receptors. This can be examined using a modification of the light microscopic autoradiographic technique for localizing BZ receptors which involves the use of CL218,872 to selectively block binding to type 1 receptors (Young et al., 1981).

The current study utilizes this modified $\mathrm{BZ}$ receptor localization method to quantitatively determine both the total $\mathrm{BZ}$ receptor density and the type 1 :type 2 receptor ratio in the nuclear subdivisions of the rat amygdala at several levels encompassing its rostrocaudal extent.

\section{Materials and Methods}

$\mathrm{BZ}$ receptors were labeled in $8-\mu \mathrm{m}$ coronal sections of rat brain according to previously established procedures (Young et al., 1981). Briefly, thaw-mounted cryostat sections were incubated for $40 \mathrm{~min}$ with $1 \mathrm{nM}\left[{ }^{3} \mathrm{H}\right]$ flunitrazepam $\left(\left[{ }^{3} \mathrm{H}\right] \mathrm{FLU}, 86.4 \mathrm{Ci} / \mathrm{mmol}\right.$; New England Nuclear, Boston, MA) at $4^{\circ} \mathrm{C}$ in $0.17 \mathrm{M}$ Tris-HCl, $\mathrm{pH}$ 7.4. The sections were then washed for $2 \mathrm{~min}$ in the same buffer, briefly rinsed in distilled water, and dried under a stream of cool, dry air. Blanks were generated by the inclusion of $1 \mu \mathrm{M}$ clonazepam in the incubation medium. Following incubation and drying, autoradiograms were generated by the apposition of emulsion-coated coverslips for a 2-week exposure period. Grain densities were determined using a Zeiss Universal microscope equipped with an eyepiece overladen with a calibrated grid. Molar densities were obtained from grain counts by comparison with a standard curve. The standards consisted of sections of brain paste containing known amounts of radioactivity. Slides containing eight such sections with in- creasing amounts of radioactivity were also apposed to emulsion-coated coverslips and co-exposed with the autoradiograms (Unnerstall et al., 1981).

Type 1 and type $2 \mathrm{BZ}$ receptors were differentiated by the addition of $200 \mathrm{nM}$ CL218,872 to the incubation medium, as previously described (Young et al., 1981). Assuming a $K_{D}$ value of $1 \mathrm{nM}$ for $\left[{ }^{3} \mathrm{H}\right] \mathrm{FLU}$ at both type 1 and type 2 sites (Young et al., 1981), and $K_{i}$ values of $10 \mathrm{nM}$ and $1000 \mathrm{nM}$ for CL218,872 at types 1 and 2 sites (Niehoff and Kuhar, 1982; Yamamura et al., 1980), respectively, the occupancy of type 1 sites in the presence of $200 \mathrm{nM}$ CL218,872 is $8 \%$, whereas that of type 2 receptors is $45 \%$ compared to a $50 \%$ occupancy by $\left[{ }^{3} \mathrm{H}\right]$ FLU at both sites in the absence of CL218,872. Thus, $200 \mathrm{nM}$ CL218,872 displaces $84 \%$ of the type 1 receptors labeled by $1 \mathrm{nM}\left[{ }^{3} \mathrm{H}\right] \mathrm{FLU}$ and $10 \%$ of the type 2 receptors, and the density of type 1- and type 2-specific binding sites can be computed by using the following set of simultaneous equations:

Type $1+$ Type $2=$ Total Binding

0.84 Type $1+0.10$ Type $2=$ Binding displaced by $200 \mathrm{nM}$ CL218,872

By incubating serial sections in the presence and $a b-$ sence of $200 \mathrm{nM}$ CL218,872, values can be obtained for total and displaceable binding in any brain region of interest and inserted into the simultaneous equations to obtain the density of type 1 and type 2 receptors.

Both total BZ receptor density and type 1/type 2 densities were determined in 10 amygdaloid nuclei, as well as the anterior amygdaloid area, from a level just posterior to the anterior commissure (A6670; Konig and Klippel, 1963) to the most caudal aspect of the amygdala (A2790; Konig and Klippel, 1963). Anatomical differentiation of the various nuclei, as well as terminology, are taken from Krettek and Price (1978).

\section{Results}

As previously demonstrated elsewhere (Unnerstall et al., 1981), grain density in the autoradiographic standards increased in a nonlinear fashion with increasing radioactivity (data not shown). Logarithmic transformation of the data yielded a linear function for the standard curve with a slope of 0.482 . Grain densities were converted to $\mathrm{dpm} / \mathrm{mg}$ of tissue by use of this curve, and molar densities were obtained by use of these values and the specific activity of the ligand. Grain densities varied by less than $10 \%$ in identical standard sections apposed to three separate coverslips.

In total, data from nine levels of the amygdaloid nuclear complex are presented. Figures 1 to 5 are schematic representations of total $\mathrm{BZ}$ receptor densities as well as the percentage of total binding comprised by type 1 receptors at each of these levels. Figures 6 to 8 are darkfield photomicrographs of brain sections incubated with $1 \mathrm{nM}\left[{ }^{3} \mathrm{H}\right] \mathrm{FLU}$ alone or with $1 \mathrm{nM}\left[{ }^{3} \mathrm{H}\right] \mathrm{FLU}$ and $200 \mathrm{~nm}$ CL218,872 at three representative levels, A5780, A4620, and A2790 (Konig and Klippel, 1963).

In general, the density of $\mathrm{BZ}$ receptors ranged from moderate to very dense throughout the amygdala, as well as in adjacent olfactory structures, i.e., the periamygdaloid and pyriform cortices and the nucleus of the lateral olfactory tract (Figs. 1 to 8). The lateral nucleus, the 

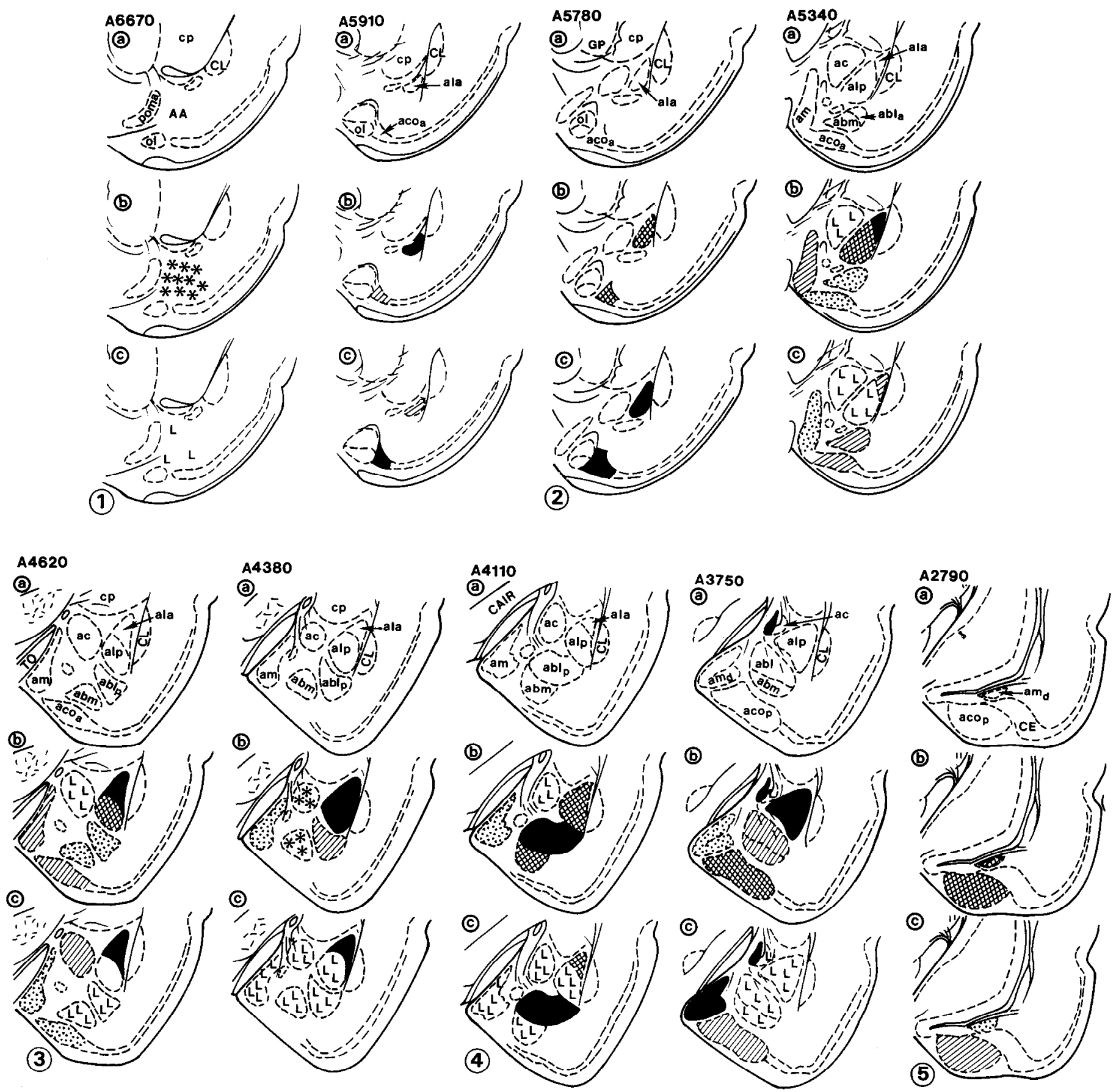

Figures 1 to $5 .^{3}$ Schematic representation of total BZ receptor density and type 1 receptor density in the rat amygdala. The upper drawing of each group of three $(a)$ defines the amygdaloid nuclei and related structures visible at that level. The second drawing $(b)$ portrays the total specific $\mathrm{BZ}$ receptor density, and the third $(c)$ depicts the percentage of total specific binding attributable to type 1 receptors. Values for total specific binding and CL218,872-displaceable binding were obtained by grain counting in autoradiograms generated as described under "Materials and Methods." Grain count values were converted to molar densities by use of the standard curve. Blank values were obtained in the presence of $1 \mu \mathrm{M}$ clonazepam; specific binding constituted at least $98.7 \%$ of the total binding. Line drawings are modified from Konig and Klippel (1963) with terminology revised to reflect the nuclear divisions of Krettek and Price (1978). Values for total BZ receptors $(b)$ (femtomoles per milligram of tissue) are depicted as: $\mathbf{\square},>95$;, 75 to $95 ; 0,50$ to 75 ; 圈, 35 to 50 ; 国, 25-35; 图, <25. Percentage of type 1 receptors (c) is depicted as: $\square, 70$ to $100 \%$; 四, 40 to $70 \%$; 圈, 20 to $40 \%$; 固, $<20 \%$.

${ }^{3}$ The abbreviations used in the figures are: $A A$, anterior amygdaloid area; $a b l$, basolateral amygdaloid nucleus; $a b l_{a}$, anterior division of the basolateral amygdaloid nucleus; $a b l_{p}$, posterior division of the basolateral amygdaloid nucleus; $a b m$, basomedial amygdaloid nucleus; $a c$, central amygdaloid nucleus; aco, cortical amygdaloid nucleus; $a o_{a}$, anterior cortical amygdaloid nucleus; $a c o_{p}$, posterior cortical amygdaloid nucleus; ala, anterior division of the lateral amygdaloid nucleus; alp, posterior division of the lateral amygdaloid nucleus; $a m$, medial amygdaloid nucleus; $a m_{d}$, posteriodorsal medial amygdaloid nucleus; $C A I R$, internal capsule; $C E$, dorsal division of the lateral entorhinal area; $C L$, claustrum; $c p$, caudate nucleus; $e c$, dorsal division of the lateral entorhinal area; $h i$, hippocampus; GP, globus pallidus; ol, nucleus of lateral olfactory tract; $p c$, posterior division of the prepiriform cortex; poma, preoptic nucleus; $T O$, optic tract. 

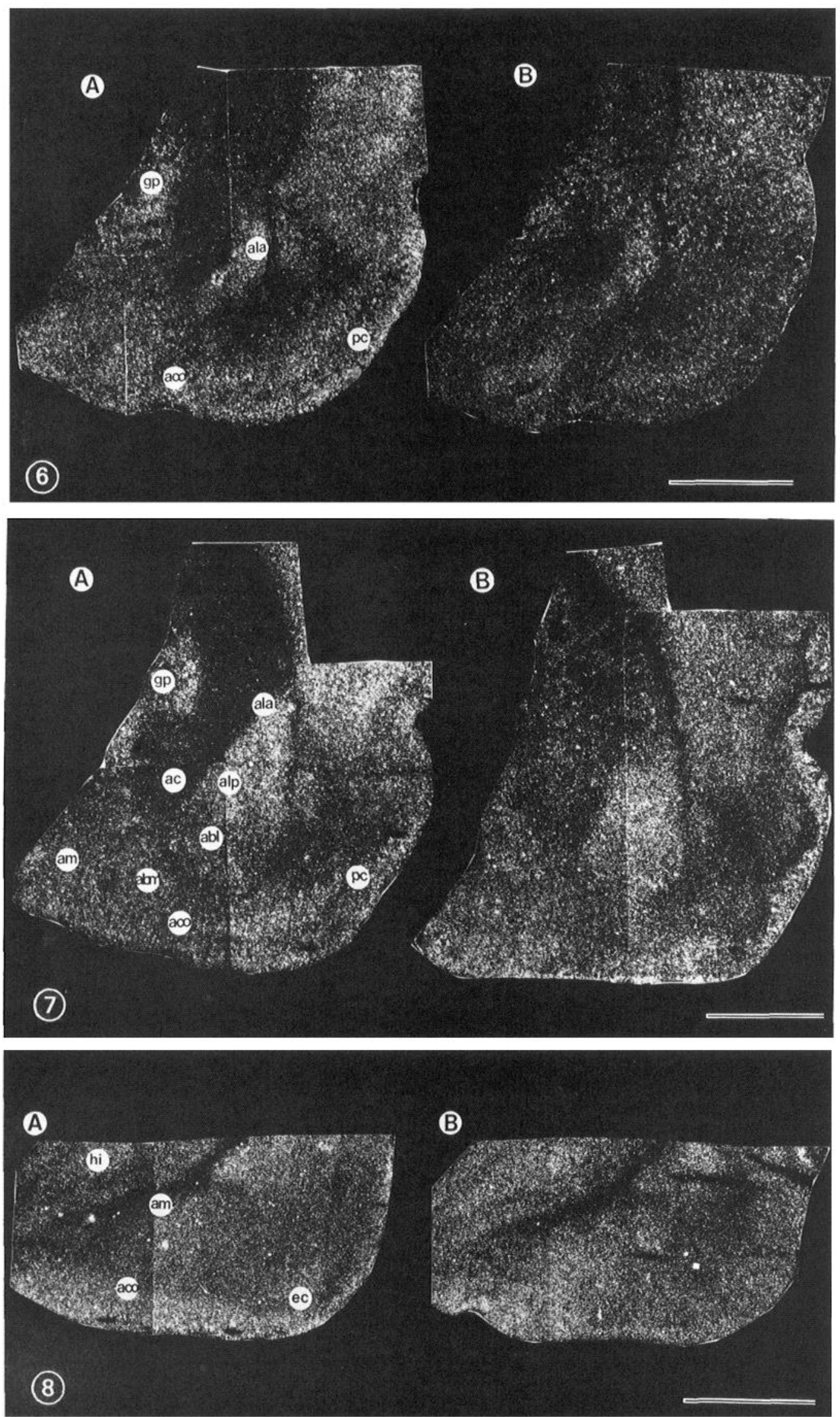

Figures 6 to 8. Darkfield photomicrographs at three representative levels of BZ receptors in the rat amygdala. In these photos, the tissue is not visible and the relative brightness is associated with grain densities. Thus, the brightest areas have the highest density of BZ binding sites. Figure 6 shows A5780, Figure 7 shows A4620, and Figure 8 shows A2970 (Konig and Klippel, 1963). The left photograph in each pair $(A)$ portrays total binding following incubation with $1 \mathrm{nM}\left[{ }^{3} \mathrm{H}\right] \mathrm{FLU}$ and that on the right $(B)$ depicts a serial section co-incubated with $200 \mathrm{nM}$ CL218,872 to inhibit binding to type 1 receptors. $B a r=100 \mu \mathrm{m}$. 
anterior and posterior cortical nuclei, and the more caudal aspect of the posterior basolateral nucleus contained the highest total densities of $\mathrm{BZ}$ receptors, whereas the central nucleus consistently displayed the lowest density of receptors. The majority of the receptors were of the type 2 subclass, although some nuclei contained a sizeable proportion of type 1 receptors, particularly in the more anterior portions of the amygdala. The analysis of total and subtype receptor densities in individual nuclei revealed localization patterns consistent with cytoarchitectonic divisions of the nuclei and, in some cases, pronounced rostral-caudal gradients. The anterior and posterior divisions of the lateral nucleus in the rat can be differentiated on the basis of cell size, with tbe anterior division composed of smaller, more tightly packed cells (Krettek and Price, 1978). Both divisions contained a high density of $\mathrm{BZ}$ receptors (Figs. 1 to 8 ), with the anterior division being slightly enriched (Figs. 1 to 3 ). The posterior division contained slightly higher levels at its more caudal aspect (A4380 and beyond, Figs. 2 to 4, 6 , and 7). The most striking difference between the two divisions was the high relative density of type 1 receptors in the anterior division.

The central nucleus contained the lowest density of $\mathrm{BZ}$ receptors, and the majority of these receptors were of the type 2 subclass. No attempt was made to distinguish receptor densities in the lateral versus the medial subdivisions (Krettek and Price, 1978) of this nucleus. The basomedial nucleus also contained relatively low receptor densities, except in its most caudal aspects. Overall, it also contained primarily type 2 receptors (Figs. 1 to 7 ).

Like the anterior and posterior subdivisions of the lateral nucleus, the basolateral nucleus can be subdivided into a magnocellular anterior division and a parvocellular posterior part (Krettek and Price, 1978). The anterior division contained a moderately high density of total BZ receptors about equally divided between the two subtypes (Fig. 2). The posterior portion contains a gradient in the total receptor density which rises to a peak at A4110 (Figs. 3 and 4) and then declines sharply. A similar, steeper gradient in the proportion of type 1 receptors paralleled the total density distribution (Figs. 3 and 4).

The medial nucleus can be separated into an anterior division and a compact, small-celled posterodorsal division (Krettek and Price, 1978). The total density of BZ receptors in the cellular layer (II) remained relatively constant over the extent of both nuclei until the most posterior levels, where it declines sharply (Figs. 2 to 7 ). Within the anterior portion, the density of Type 1 receptors declines rostrocaudally from moderately high to nonexistent, while a peak of type 1 receptors marks the anterior posterodorsal border of the medial nucleus (Figs. 2 to 7 ).

The cellular layer (II) of the anterior cortical nucleus (Krettek and Price, 1978) contains a high density of BZ receptors. The anterior aspects of this nucleus are unique in that they contain the highest density of type 1 receptors (Figs. 1, 2, and 6) in the amygdala. The level of type 1 receptors declines gradually, rostrocaudally (Figs. 1 to $3)$.

The posterior cortical nucleus is highly enriched in BZ receptors (Figs. 4, 5, and 8 ). This nucleus contained
TABLE I

Distribution of $B Z$ receptors in the rat amygdala

$\mathrm{BZ}$ receptor density was determined in autoradiograms generated by incubating $8-\mu \mathrm{m}$ coronal sections of rat brain with $1 \mathrm{nM}\left[{ }^{3} \mathrm{H}\right] \mathrm{FLU}$ as described under "Materials and Methods" by grain counting. Values for grain density were converted to molar densities by use of the standard curve. Blank values were obtained in the presence of $1 \mu \mathrm{M}$ clonazepam; specific binding constituted at least $98.7 \%$ of the total binding.

\begin{tabular}{|c|c|c|c|}
\hline \multirow[b]{2}{*}{ Level $^{a}$} & \multicolumn{3}{|c|}{ Total Specific Receptor Density } \\
\hline & $\begin{array}{c}\text { Entire } \\
\text { amygdaloid } \\
\text { complex }^{b}\end{array}$ & $\begin{array}{c}\text { Basolateral } \\
\text { complex } \\
\text { only }\end{array}$ & $\begin{array}{l}\text { Corticomedial } \\
\text { complex } \\
\text { only }\end{array}$ \\
\hline & \multicolumn{3}{|c|}{ fmol/mg of tissue } \\
\hline A5910 & 158.9 & 97.7 & 61.2 \\
\hline A5780 & 162.5 & 74.7 & 87.8 \\
\hline A5340 & 376.4 & 261.9 & 114.5 \\
\hline A 4620 & 404.6 & 286.4 & 118.2 \\
\hline A4380 & 395.5 & 328.8 & 66.7 \\
\hline A4110 & 409.5 & 353.5 & 56.0 \\
\hline A3990 & 369.7 & 229.1 & 140.6 \\
\hline A2970 & 92.2 & N/A & 92.2 \\
\hline
\end{tabular}

${ }^{a}$ From Konig and Klippel (1963).

${ }^{b}$ Refers to the summation of densities in all of the nuclei visible at that anatomical level.

${ }^{c}$ Consists of basal and lateral nuclei.

${ }^{d}$ Consists of central, cortical, and medial nuclei.

${ }^{e} \mathrm{~N} / \mathrm{A}$, not determined at this level, due to the extremely restricted size of these nuclei.

moderately high levels of type 1 receptors (Figs. 4, 5, and 8).

The anterior amygdaloid area contains low levels of type $2 \mathrm{BZ}$ receptors (Fig. 1). Table I summarizes the distribution of total $\mathrm{BZ}$ receptor density in the entire emygdaloid nuclear complex, as well as in its basolateral and corticomedial nuclear subdivisions at all levels examined in this study. It is clear from this table that the basolateral subdivision contains far more $\mathrm{BZ}$ receptors than does the corticomedial division at all levels. Table II provides a similar summary of the type 1 receptor subtype distribution and reveals an overall enrichment of this subtype in the more anterior aspects of the amygdala. The corticomedial subdivision also contains an additional peak in type 1 receptor density in its more caudal aspects, coinciding with the appearance of the posterior cortical nucleus and posteriodorsal medial nucleus, in contrast with a gradual decline in type 1 density rostrocaudally in the basolateral complex.

\section{Discussion}

The results obtained in this study demonstrate a high density of $\mathrm{BZ}$ receptors in the rat amygdala and also identify the majority of these receptors as being of the type 2 subclass. Total $\mathrm{BZ}$ receptor density appeared to be much higher in the phylogenetically recent basolateral (basal and lateral nuclei) nuclear subgroup as opposed to the more primitive corticomedial (cortical, medial, and central nuclei) subgroup at most levels examined. ${ }^{4}$ Type 1 receptors appeared to be restricted to a few nuclei and

\footnotetext{
${ }^{4}$ Recent data obtained in human amygdala indicate a similar concentration of $\mathrm{BZ}$ receptors in the basolateral nuclear division, especially the lateral nucleus (D. L. Niehoff and P. J. Whitehouse, manuscript in preparation).
} 
TABLE II

Distribution of type 1 receptors in the rat amygdala

Total and CL-displaceable BZ receptor densities were determined by grain counting in $8-\mu \mathrm{m}$ coronal rat brain sections incubated with 1 $\mathrm{nM}\left[{ }^{3} \mathrm{H}\right] \mathrm{FLU}$ in the presence or absence of $200 \mathrm{nM}$ CL218,872 as described under "Materials and Methods." Values for type 1 and type 2 receptors were obtained by use of the simultaneous equations:

Type $1+$ Type $2=$ Total receptor density

0.84 Type $1+0.1$ Type $2=$ CL-displaceable receptor density

Blank values were obtained in the presence of $1 \mu \mathrm{M}$ clonazepam; specific binding constituted at least $98.7 \%$ of the total binding.

\begin{tabular}{cccc}
\hline & \multicolumn{3}{c}{$\begin{array}{c}\text { Percentage of Total Specific Receptor Density } \\
\text { Comprised by Type 1 Receptors }\end{array}$} \\
\cline { 2 - 4 } Level $^{a}$ & $\begin{array}{c}\text { Entire } \\
\text { amygdaloid } \\
\text { complex }^{b}\end{array}$ & $\begin{array}{c}\text { Basolateral } \\
\text { complex } \\
\text { only }\end{array}$ & $\begin{array}{c}\text { Corticomedial } \\
\text { complex }^{d} \\
\text { only }\end{array}$ \\
\hline A5910 & 70.6 & 66.6 & 77.1 \\
A5780 & 80.0 & 69.8 & 88.8 \\
A5340 & 40.2 & 41.1 & 38.4 \\
A4620 & 35.7 & 37.1 & 32.3 \\
A4380 & 44.0 & 50.4 & 12.4 \\
A4110 & 40.1 & 45.4 & 6.3 \\
A3990 & 31.6 & 12.5 & 67.7 \\
A2970 & 32.8 & N/A $^{e}$ & 32.8 \\
\hline
\end{tabular}

${ }^{a}$ From Konig and Klippel (1963).

${ }^{b}$ Refers to the percentage of type 1 receplors overall in all of the nuclei visible at that anatomical level.

' Consists of basal and lateral nuclei.

${ }^{d}$ Consists of central, cortical, and medial nuclei.

e N/A, not determined at this level, due to the extremely restricted size of these nuclei.

to follow a pronounced rostrocaudal decline within those nuclei. In the rest of the amygdala, type 1 receptors comprised at hest 30 to $40 \%$ of the overall receptor density and were undetectable at some levels in some nuclei. The highest levels of type 1 receptors were located in the anterior cortical nucleus and anterior lateral nucleus, while the highest levels of type 2 receptors were found in the posterior lateral nucleus, the basomedial nucleus, and the central nucleus. Thus, type 1 receptors appear to be concentrated in the more anterior portions of the amygdala.

Our results confirm our previous autoradiographic studies identifying the amygdala as a region of high BZ receptor density (Young and Kuhar, 1980). The anatomical distribution of total $\mathrm{BZ}$ receptor density in the various amygdaloid nuclei would tend to suggest that the basolateral nuclear subgroup might be the more important in mediating the actions of BZs. The behavioral evidence implicating the lateral amygdala as a site important in fearful responses and fear-inducing operant paradigms (Ursin and Kaada, 1960; Pellegrino, 1968; Ursin, 1971; Swartzwelder, 1981), as well as studies which have elicited the anxiolytic action of BZs by direct application (Scheel-Kruger and Petersen, 1982) to the lateral or basolateral nuclei support this possibility. Surprisingly, these nuclei contain relatively few type 1 receptors at most levels examined. Thus, the idea that type 1 receptors are primarily associated with the therapeutic actions of BZs, whereas type 2 receptors are associated with unwanted side effects (Lippa et al., 1979a, b) seems less plausible, although one cannot rule out that the low levels of type 1 receptors are important.

High levels of BZ receptors are found in other limbic and cortical regions that receive projections from the amygdala. These include the hippocampus, subiculum, ventromedial hypothalmus, and lamina IV of the cerebral cortex (Young and Kuhar, 1981), suggesting that certain neuroanatomical pathways will be strongly influenced by BZ drugs. The activation of such pathways may be related to anxiogenic and fearful responses or a basis of seizure induction. For example, amygdaloid-kindled seizures have been shown to result in alterations in hippocampal BZ receptors (McNamara et al., 1980), and local destruction of amygdaloid neurons by the application of a kainic acid has been shown to result in hippocampal degeneration and a seizure pattern resembling status epilepticus (Ben-Ari et al., 1979). As the lateral and basolateral amygdaloid nuclei are connected to the hippocampus in the rat via the lateral entorhinal area and subiculum, respectively (Krettek and Price, 1977, 1978), a pathway comprised of amygdala-entorhinal cortex/ subiculum-hippocampus may be the anatomical basis of these observations. Similarly, a recent study identified the mammillary body as another site at which direct application of BZs could elicit potent anticonflict activity (Kataoka et al., 1982) and outlined a pathway to mediate this activity composed of mammillary body $\rightarrow$ anterior thalamus (Cruce, 1975; 1977) $\rightarrow$ frontal cortex (Domesick, 1972; Divac et al., 1978). As the mamillary body receives an input from the ventromedial hypothalamus, which in turn receives input from the basomedial and medial nuclei of the amygdala (Krettek and Price, 1978), a possible extension of this pathway would include: lateral amygdaloid nucleus-basomedial amygdaloid nucleus (Krettek and Price, 1978)-ventromedial hypothalamus (Krettek and Price, 1978)-mammillary body-anterior thalamus-frontal cortex. Direct connections between the basolateral and lateral nuclei and frontal cortex (Krettek and Price, 1978) may also be important in the anticonflict effects of BZs. Lippa et al. (1979a, b) have shown that the frontal cortex was important in the disinhibition of punished behavior by BZs. These proposed pathways suggest alternative sites for future direct application and lesion studies to further localize the therapeutic actions of BZs. A preliminary report of these data has appeared (Niehoff and Kuhar, 1982).

\section{References}

Ben-Ari, Y., J. Jagowka, E. Tremblay, and G. le Gal la Salle (1979) A new model of focal status epilepticus: Intra-amygdaloid application of kainic acid elicits repetitive secondarily generalized convulsive seizures. Brain Res. 163: 176-179.

Chapman, W. P., H. R. Schroeder, G. Geyer, M. A. B. Brazier, C. Fager, J. L. Poppen, H. C. Solomon, and P. I. Yakolev (1954) Physiological evidence concerning the importance of the amygdaloid nuclear region in the integration of circulating function and emotion in man. Science 129: 949-950.

Chou, D. T., and S. C. Wang (1977) Unit activity of amygdala and hippocampal neurons: Effects of morphine and benzodiazepines. Brain Res. 126: 427-440.

Cruce, J. A. F.(1975) An autoradiographic study of the projec- 
tions of the mammillothalamic tract in the rat. Brain Res. 85: $211-219$.

Cruce, J. A. F. (1977) An autoradiographic study of the descending connections of the mammillary nuclei of the rat. J. Comp. Neurol. 176: 631644.

Divac, I., A. Kosmal, A. Bjorklund, and O. Lindvall (1978) Subcortical projections ot the prefrontal cortex in the rat as revealed by the horseradish peroxidase technique. Neuroscience 3: 785-796.

Domesick, V. B. (1972) Thalamic relationships of the medial cortex in the rat. Brain Behav. Evol. 6: 457-483.

Eidelberg, E., H. M. Neer, and M. K. Miller (1965) Anticonvulsant properties of some benzodiazepine derivatives. Neurology 15: 223-230.

Haefely, W., L. Pieri, P. Pole, and R. Schaffer (1981) General pharmacology of benzodiazepine derivatives. In Handbook of Experimental Pharmacology, F. Hoffmeister, ed., pp. 1-183, Springer-Verlag, New York.

Haller, J. (1979) Quantification of the psychotropic drug-induced changes in the feline EEK. Ph.D. dissertation, University of Basel, Basel, Switzerland.

Kataoka, Y., K. Shibata, Y. Gomita, and S. Ueki (1982) The mamillary body is a potential site of antianxiety action of benzodiazepines. Brain Res. 241: 374-377.

Klepner, C. A., A. S. Lippa, D. I. Benson, M. C. Sano, and B. Beer (1979) Resolution of two biochemically and pharmacologically distinct benzodiazepine receptors. Pharmacol. Biochem. Behav. 11: 457-462.

Konig, J. R., and R. A. Klippel (1963) The Rat Brain: A Stereotaxic Atlas of the Forebrain and Lower Parts of the Brainstem, Robert E. Krieger Publishing Co., Inc., New York.

Krettek, J. E. and J. L. Price (1977) Projections from the amygdaloid complex and adjacent olfactory structures to the entorhinal cortex and subiculum in rat and cat. J. Comp. Neurol. 172: 723-752.

Krettek, J. E. and J. L. Price (1978) A description of the amygdaloid complex in the rat and cat, with observations on intra-amygdaloid axonal connections. J. Comp. Neurol. 178: $255-280$.

Lippa, A. S., L. J. Critchett, M. C. Sano, C. A. Klepner, E. N. Greenblatt, J. Coupet, and B. Beer (1979a) Benzodiazepine receptors: Cellular and behavioral characteristics. Pharmacol. Biochem. Behav. 10: 831-843.

Lippa, A. S., J. Coupet, E. N. Greenblatt, C. A. Klepner, and B. Beer (1979b) A synthetic nonbenzodiazepine ligand for benzodiazepine receptors: A probe for investigating neuronal substrates of anxiety. Pharmacol. Biochem. Behav. 11: 99106.

McNamara, J. O., A. M. Peper, and V. Patrone (1980) Repeated seizures induce long-term increase in hippocampal benzodiazepine receptors. Proc. Natl. Acad. Sci. U. S. A. 77: 30293032.

Nagy, J., and L. Desci (1973) Location of the site of the tranquilizing action of diazepam by intralimbic application. Neuropharmacology 12: 757-768.

Nagy, J., and L. Desci (1979) Further studies on the site of action of diazepam: Anticonvulsant effect in the rabbit. Neuropharmacology 18: 39-45.

Nagy, J., K. Zambo, and L. Desci (1979) Anti-anxiety action of diazepam after intra-amygdaloid application in the rat. Neuropharmacology 18: 573-576.

Niehoff, D. L., and M. J. Kuhar (1982) Benzodiazepine receptors: Autoradiographic localization in rat and human amygdala. Soc. Neurosci. 8: 645.

Pellegrino, L. (1968) Amygdaloid lesions and behavioral inhibition in the rat. J. Comp. Physiol. Psychol. 65: 483-491.

Scheel-Kruger, J., and E. N. Petersen (1982) Anticonflict effect of the benzodiazepines mediated by a GABAergic mechanism in the amygdala. Eur. J. Pharmacol. 82: 115-116.

Shipata, K., Y. Kataoka, Y. Gomita, and S. Ueki. (1982) Localization of the site of the anticonflict of benzodiazepines in the amygdaloid nucleus of rats. Brain Res. 234: 442-446.

Squires, R. F., D. I. Benson, C. Braestrup, J. Coupet, C. A. Klepner, V. Myers, and B. Beer (1979) Some properties of brain specific benzodiazepine receptors: New evidence for multiple receptors. Pharmacol. Biochem. Behav. 10: 825-830.

Swartzwelder, H. S. (1980) Deficits in passive avoidance and fear behavior following bilateral and unilateral amygdala lesions in mice. Physiol. Behav. 26: 323-326.

Unmeto, M., and M. E. Olds (1975) Effects of chlordiazepoxide, diazepam, and chlorpromazine on conditional emotional behavior and conditioned neuronal activity in limbic, hypothalamic, and geniculate regions. Neuropharmacology 14: 413425.

Unnerstall, J. R., M. J. Kuhar, D. L. Niehoff, and J. M. Palacios (1981) Benzodiazepine receptors may be coupled to a subpopulation of GABA receptors: Evidence from a quantitative autoradiographic study. J. Pharmacol. Exp. Ther. 218: 797804.

Ursin, H. (1971) Limbic control of emotional behavior. In Proceedings, Second Conference on Psychosurgery, E. R. Hitchcock and K. Varnet, eds., Charles C Thomas, Springfield, IL.

Ursin, H., and B. B. Kaada (1960) Functional localization within the amygdaloid complex in the cat. Electroencephalogr. Clin. Neurophysiol. 12: 1-20.

Yamamura, H. I., T. Mimaki, D. Horst, and R. O'Brien (1980) $\left({ }^{3} \mathrm{H}\right) \mathrm{CL} 218872$, a novel traizolopyridazine which labels the benzodiazepine receptor. Fed. Proc. 40: 310.

Young, W. S., III, and M. J. Kuhar (1980) Radiohistochemical localization of benzodiazepine receptors in rat brain. J. Pharmacol. Exp. Ther. 212: 337-346.

Young, W. S., III, D. L. Nichoff, M. J. Kuhar, B. Beer, and A. S. Lippa (1981) Multiple benzodiazepine receptor localization by light microscopic radiohistochemistry. J. Pharmacol. Exp. Ther. 216: $425-430$. 